\title{
Evaluation of Nutrient Supplementation to Charcoal- Treated and Untreated Rice Straw Hydrolysate for Xylitol Production by Candida guilliermondii
}

\author{
Solange Inês Mussatto* and Inês Conceição Roberto \\ Departamento de Biotecnologia; Faculdade de Engenharia Química de Lorena; Rodovia Itajubá-Lorena, Km 74,5; \\ C.P. 116; solange@debiq.faenquil.br; 12600-970; Lorena-SP - Brazil
}

\begin{abstract}
Xylitol was produced by Candida guilliermondii from charcoal-treated and untreated rice straw hemicellulosic hydrolysate with or without nutrients (ammonium sulphate, calcium chloride, rice bran extract). Both, xylitol yield and volumetric productivity decreased significantly when the nutrients were added to treated and untreated hydrolysates. In the treated hydrolysate, the efficiency of xylose conversion to xylitol was $79 \%$ when the nutrients were omitted. The results demonstrated that rice straw hemicellulosic hydrolysate treated with activated charcoal was a cheap source of xylose and other nutrients for xylitol production by $\mathrm{C}$. guilliermondii. The non-necessity of adding nutrients to the hydrolysate media would be very advantageous since the process becomes less costly.
\end{abstract}

Key words: Rice straw hydrolysate, nutrient, activated charcoal, Candida guilliermondii, xylitol

\section{INTRODUCTION}

Rice straw is a fibrous lignocellulosic material that differs from most crop residues in its high content of silicon dioxide $\left(\mathrm{SiO}_{2}\right)$. Ash content on a dry weight basis ranges from 13 to $20 \%$, varying according to the state of conservation of the straw after harvest. Ash generally contains $75 \% \mathrm{SiO}_{2}$, $10 \% \mathrm{~K}_{2} \mathrm{O}, 3 \% \mathrm{P}_{2} \mathrm{O}_{5}, 3 \% \mathrm{Fe}_{2} \mathrm{O}_{3}, 1.3 \% \mathrm{CaO}$ and smaller amounts of $\mathrm{Mg}, \mathrm{S}$, and $\mathrm{Na}$ (Kadam et al., 2000). Rice straw also contains a large amount of hemicellulose fraction that can be easily hydrolysed to its constituent carbohydrates, a mixture of sugars, containing mainly xylose (Roberto et al., 2003). Xylose solution obtained can be used as a fermentation medium to produce xylitol (Silva and Roberto, 1999, 2001; Mussatto and Roberto, 2003), a five-carbon sugar alcohol and a food edulcorant with clinical properties and considerable pharmaceutical applications (Mussatto and Roberto, 2002).

All published data on xylitol production by yeasts have demonstrated that xylitol accumulation is influenced by a number of experimental conditions. Studying the effect of these conditions is of particular interest as a prerequisite for higher xylitol yields and productivities (Winkelhausen and Kuzmanova, 1998). Major improvements in the productivity of bioconversion processes are generally ascribed to the development of superior microbial strains by mutation. However, other parameters such as the nutritional and physical environment to which an organism is exposed are also known to alter product yield significantly (Greashan and Inamine, 1996). Hydrolysate treatment with activated charcoal has also been considered as a good method to overcome microbial inhibition caused by toxic substances,

\footnotetext{
*Author for correspondence
} 
improving the fermentability of the hydrolysate (Winkelhausen and Kuzmanova, 1998; Mussatto and Roberto, 2001; Mussatto, 2002). However, besides removing toxic substances, the charcoal can also adsorb compounds that are essential to the microbial growth.

The present study evaluated the effect of nutrient supplementation to rice straw hydrolysates on xylitol production by Candida guilliermondii.

\section{MATERIALS AND METHODS}

\section{Hemicellulosic Hydrolysate}

Rice straw containing (\% w/w) 43.5 cellulose, 22.0 hemicellulose, 17.2 lignin and 11.4 ash (Mussatto, 2002) was dried in the sun and milled to attain particles of about $1 \mathrm{~cm}$ in length and 1 $\mathrm{mm}$ in thickness. The hemicellulosic hydrolysate was obtained by acid hydrolysis in a 350-1 stainless-steel pressure reactor as described by Roberto et al. (2003) and subsequently was concentrated (under vacuum) in a 4-l evaporator at $70 \pm 5^{\circ} \mathrm{C}$ to obtain a xylose content of approximately $150 \mathrm{~g} / \mathrm{l}$. The concentrated hydrolysate was over-titrated with $\mathrm{NaOH}$ (pellets) to $\mathrm{pH} 8.0$ and adjusted to $\mathrm{pH} 6.5$ with concentrated sulphuric acid. This was termed as untreated hydrolysate. The hydrolysate was mixed with activated charcoal (40 $\mathrm{g}$ of hydrolysate per $\mathrm{g}$ of charcoal) and after agitation at $200 \mathrm{rpm}, 30^{\circ} \mathrm{C}$ for $1 \mathrm{~h}$, the charcoal was removed by centrifugation at $2000 \mathrm{xg}$ for $20 \mathrm{~min}$. This was termed as treated hydrolysate.

\section{Inoculum Preparation}

Strain of Candida guilliermondii FTI 20037 was maintained at $4^{\circ} \mathrm{C}$ on malt extract agar slants. The inoculum was prepared by growing cells in $125 \mathrm{ml}$ flasks containing $50 \mathrm{ml}$ medium composed of (g/l): xylose 20, $\left(\mathrm{NH}_{4}\right)_{2} \mathrm{SO}_{4} 3, \mathrm{CaCl}_{2} \cdot 2 \mathrm{H}_{2} \mathrm{O} 0.1$ and rice bran extract $(20 \% \mathrm{v} / \mathrm{v})$. A $10 \% \mathrm{w} / \mathrm{v}$ suspension of rice bran was sterilised by autoclaving at $121^{\circ} \mathrm{C}$ for $20 \mathrm{~min}$, and cooled to ambient temperature. This suspension was then aseptically centrifuged at $2000 \mathrm{xg}$ for $20 \mathrm{~min}$. The liquid fraction (rice bran extract) was stored at $4^{\circ} \mathrm{C}$ for one day. The solutions were sterilised by autoclaving at $121^{\circ} \mathrm{C}$ for $20 \mathrm{~min}$, except xylose solution, which was autoclaved at $112^{\circ} \mathrm{C}$ for $15 \mathrm{~min}$. The microorganism was cultivated in a rotatory shaker $(200 \mathrm{rpm})$ at $30^{\circ} \mathrm{C}$ for $24 \mathrm{~h}$ and the cells were separated by a 20 min centrifugation at $2000 \mathrm{xg}$ and resuspended in sterilised water to obtain a dense cell suspension (about $30 \mathrm{~g} / \mathrm{l}$ ).

\section{Media and Culture Conditions}

Assays were performed using 125-ml Erlenmeyer flasks closed with cotton-wool plugs, containing $50 \mathrm{ml}$ of medium consisting of charcoal-treated and untreated hydrolyzates, diluted to $85 \mathrm{~g} / \mathrm{l}$ xylose, supplemented with or without nutrients (ammonium sulphate $(3 \mathrm{~g} / \mathrm{l})$, calcium chloride $(0.1$ $\mathrm{g} / \mathrm{l})$ and rice bran extract $(20 \% \mathrm{v} / \mathrm{v}))$ and inoculated to obtain an initial cell concentration of $3.0 \mathrm{~g} / \mathrm{l}$. Fermentation was carried out on an orbital shaker at $250 \mathrm{rpm}, 30^{\circ} \mathrm{C}$ for $96 \mathrm{~h}$. A $2^{2}$ factorial design in order to determine the effect of the charcoal treatment (factor A) and nutrient supplementation (factor B) on the xylitol production was employed. The levels of the factors were conveniently coded into minus and plus signs.

\section{Analytical Methods}

Sugars and xylitol concentrations were determined by HPLC using a refractive index (RI) detector and a Bio-Rad HPX - 87H (300 x $7.8 \mathrm{~mm})$ column, a temperature of $45^{\circ} \mathrm{C} ; 0.005 \mathrm{M}$ sulphuric acid as the eluent, flow of $0.6 \mathrm{ml} / \mathrm{min}$ and sample volume of $20 \mu \mathrm{l}$. Cell growth was evaluated spectrophotometrically at $600 \mathrm{~nm}$, and estimated by means of a calibration curve (dry weight $\mathrm{x}$ optical density at $600 \mathrm{~nm}$ ) obtained from growing cells on hydrolysate medium on a rotatory shaker at $250 \mathrm{rpm}, 30^{\circ} \mathrm{C}$ for $72 \mathrm{~h}$.

\section{RESULTS AND DISCUSSION}

Expensive nitrogen sources (e.g. yeast extract and peptone) and various minerals have been used to supplement xylose culture media for xylitol production by yeasts (Azuma et al., 2000; Walter et al., 2001; Canettieri et al., 2001). However, when hemicellulose hydrolysates are used as culture media, the need for supplementation should be minimised, since they contain not only fermentable sugars, but also compounds that are essential for cell growth (Preziosi-Belloy et al., 2000; Canettieri et al., 2001). Considering that the cost of the culture medium is a decisive factor in determining the economic viability of the bioconversion process, it is very important to 
define the minimal nutrient requirements for the hydrolysate bioconversion.

Recently, some studies have demonstrated that the hemicellulosic hydrolysates fermentability can be significantly improved by removing inhibitors compounds (Mussatto and Roberto, 2001; Mussatto, 2002) and by supplementing with nutrients (Preziosi-Belloy et al., 2000; Almeida e Silva et al., 2003).

The results of treated and untreated rice straw hydrolysates supplemented with or without nutrients are shown in Table 1. It could be observed that the nutrient supplementation did not affect xylose consumption, but in media without nutrient addition, both xylitol production and cell growth were favoured. After $96 \mathrm{~h}$ of bioconversion without nutrients, xylitol concentration was $40 \mathrm{~g} / \mathrm{l}$ in the untreated hydrolysate and $59 \mathrm{~g} / \mathrm{l}$ in the treated hydrolysate, showing an increase of almost $50 \%$. However, in both media supplemented with nutrients, xylitol concentration was about $30 \mathrm{~g} / \mathrm{l}$. These results suggested that the charcoal adsorption removed the potential bioconversion inhibitors, but not the compounds that were essential to the microbial metabolism. Indeed, the nutrient supplementation had a dramatic inhibiting effect on xylitol production, probably due to imbalance between the ionic nutrition, which was reflected in low tolerance to the environment. Silva and Roberto (1999) suggested that the utilisation of ammonium sulphate by the microorganisms could promote a liberation of sulphate ions, which generated $\mathrm{H}_{2} \mathrm{SO}_{4}$, decreasing the $\mathrm{pH}$ of the fermentation medium and thus, affecting the yeast activity.

A Pareto chart was used to perform a statistical analysis of the experimental data. Fig. 1 (a, b and c), represents the estimated effects of the charcoal treatment and nutrient supplementation on xylitol and biomass production, and on xylose utilisation, in descending order. The length of each bar was proportional to the standardised effect. Bars extending beyond the vertical line corresponded to effects statistically significant at $95 \%$ confidence level. It could be observed that the charcoal treatment (factor A) influenced positively all responses studied. However, nutrients supplementation (factor B) did not affect xylose utilisation and biomass concentration, showing a strong negative influence only with xylitol production. Fig. 1a also revealed that factor A (hydrolysate treatment) interacted negatively with factor B (nutrient supplementation) during xylitol production. This meant that the best results were provided by the hydrolysate treated with activated charcoal without the addition of ammonium sulphate, rice bran extract and calcium chloride.

The effects of nutrient supplementation on the bioconversion parameters of $C$. guilliermondii grown on hydrolysates treated with activated charcoal or on untreated hydrolysates are shown in Table 2. The volumetric productivity $\left(\mathrm{Q}_{\mathrm{P}}\right)$ and yield factor $\left(\mathrm{Y}_{\mathrm{P} / \mathrm{S}}\right)$ varied strongly from 0.32 to $0.62 \mathrm{~g} / \mathrm{l} . \mathrm{h}$ and from 0.40 to $0.72 \mathrm{~g} / \mathrm{g}$, respectively. The highest yield $(0.72 \mathrm{~g} / \mathrm{g})$ and productivity $(0.62$ g/l.h) were obtained when C. guilliermondii was cultivated in treated hydrolysate (initial xylose $=$ $85 \mathrm{~g} / \mathrm{l})$ without nutrient supplementation. Similar values $\left(\mathrm{Y}_{\mathrm{P} / \mathrm{S}}=0.80 \mathrm{~g} / \mathrm{g}\right.$ and $\mathrm{Q}_{\mathrm{P}}=0.58 \mathrm{~g} / \mathrm{l}$.h $)$ were reported by Preziosi-Belloy et al. (2000) for bioconversion process by C. guilliermondii from aspenwood hemicellulose hydrolysate (initial xylose $=50 \mathrm{~g} / \mathrm{l}$ ). Nevertheless, according to these authors, the addition of yeast extract $(2 \mathrm{~g} / \mathrm{l})$ to the hydrolysate was fundamental to improving bioconversion rate and xylitol yield.

Several agricultural residues can be used to produce xylitol; however, the necessity of adding nutrients in the fermentation media varies for each lignocellulosic material employed. According to Almeida e Silva et al. (2003), xylitol production from eucalyptus hemicellulosic hydrolysate was dependent on the ammonium sulphate addition in the culture medium. Pessoa Jr et al., (1996) concluded that oligoelements and vitamins were present in sugarcane bagasse hydrolysate, but no phosphate.

Thus, when compared with the other lignocellulosic materials, rice straw appeared as a more economical alternative to produce xylitol, due the non-necessity of adding nutrients to the media formulated from its hydrolysate.

The necessity of adding nutrients in hydrolysate medium formulated from other lignocellulosic materials could be due to their low quantity of ash (around 4\% w/w in sugarcane bagasse, wood and others, Kuhad and Singh, 1993). According to Kaddam et al. (2000), rice straw contained a high quantity of minerals, oligoelements and vitamins, in the ash (corresponding to $11.4 \% \mathrm{w} / \mathrm{w}$ ). For this reason, the hydrolysate obtained from rice straw could be a rich source of nutrients essential for the growth of microorganisms in fermentative process 
(a)

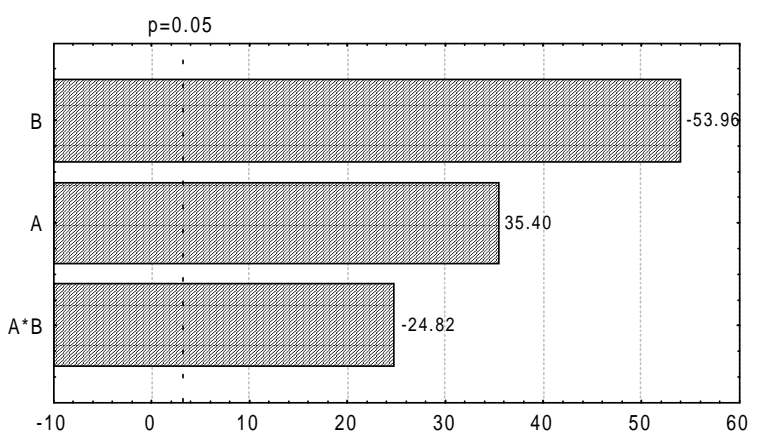

(b)

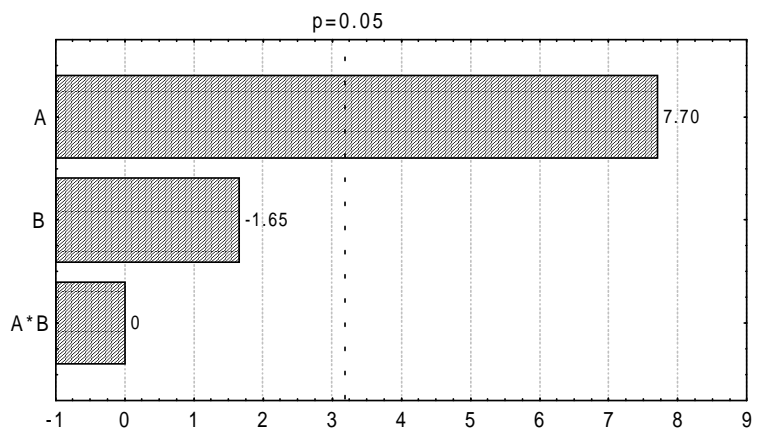

(c)

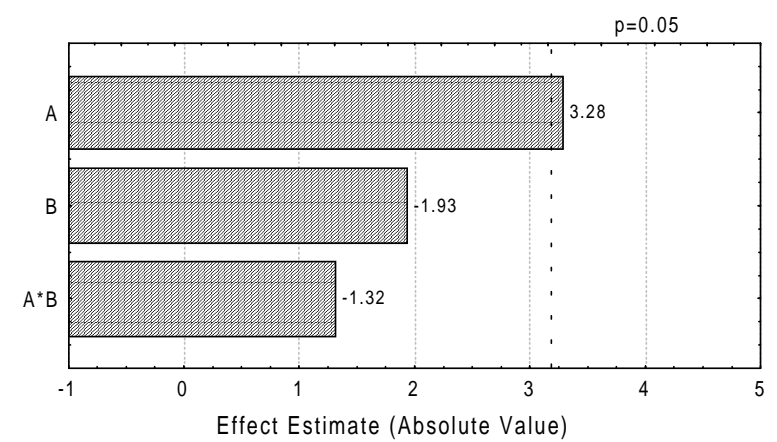

Figure 1 - Pareto chart for the effects of charcoal treatment (factor A) and nutrient supplementation (factor B) on the production of xylitol (a), and biomass (b) and on the utilisation of xylose (c) by C.guilliermondii.

Table 1 - Results of bioconversion of $C$. guilliermondii, after $96 \mathrm{~h}$ cultivation, from charcoal treated and untreated hydrolysate in response to addition of nutrients

\begin{tabular}{lcccc}
\hline \multicolumn{1}{c}{ Factors } & \multicolumn{4}{c}{ Runs N $^{\mathbf{0}}$} \\
\cline { 2 - 5 } & $\mathbf{1}$ & $\mathbf{2}$ & $\mathbf{3}$ & $\mathbf{4}$ \\
\hline Charcoal treatment (A) & - (without) & + (with) & - (without) & + (with) \\
Nutrients (B) & - (without) & - (without) & + (with) & \\
Responses & & & & 34.1 \\
Xylitol (g/l) & 40.0 & 59.1 & 30.8 & 93 \\
Xylose utilised (\%) & 82 & 94 & 79 & 9.4 \\
Biomass (g/l) & 8.0 & 12.6 & 7.4 & \\
\hline
\end{tabular}


Table 2 - Effect of nutrient supplementation on the bioconversion parameters of C. guilliermondii in the experiments with treated and untreated hydrolysates, after $96 \mathrm{~h}$

\begin{tabular}{lcccc}
\hline \multirow{2}{*}{ Parameters } & \multicolumn{2}{c}{ Untreated Hydrolysates } & \multicolumn{2}{c}{ Treated Hydrolysates } \\
\cline { 2 - 5 } & $\begin{array}{c}\text { with } \\
\text { Nutrients }\end{array}$ & $\begin{array}{c}\text { without } \\
\text { Nutrients }\end{array}$ & $\begin{array}{c}\text { with } \\
\text { Nutrients }\end{array}$ & $\begin{array}{c}\text { without } \\
\text { Nutrients }\end{array}$ \\
\hline $\mathrm{Y}_{\mathrm{P} / \mathrm{S}}(\mathrm{g} / \mathrm{g})$ & 0.45 & 0.56 & 0.40 & 0.72 \\
$\mathrm{Y}_{\mathrm{X} / \mathrm{S}}(\mathrm{g} / \mathrm{g})$ & 0.05 & 0.06 & 0.06 & 0.10 \\
$\mathrm{Q}_{\mathrm{P}}(\mathrm{g} / \mathrm{l} . \mathrm{h})$ & 0.32 & 0.42 & 0.36 & 0.62 \\
$\eta(\%)$ & 49 & 61 & 44 & 79 \\
\hline $\mathrm{Y}_{\mathrm{P}}$ & & 6 & & \\
\hline
\end{tabular}

$\mathrm{Y}_{\mathrm{P} / \mathrm{S},}$ xylitol yield coefficient, $\mathrm{g}$ xylitol per $\mathrm{g}$ xylose consumed; $\mathrm{Y}_{\mathrm{X} / \mathrm{S}}$, cell yield coefficient, $\mathrm{g}$ drycell mass per $\mathrm{g}$ xylose and glucose consumed; $\mathrm{Q}_{\mathrm{P}}$, volumetric xylitol production rate, $\mathrm{g} / \mathrm{l} . \mathrm{h} ; \eta$, efficiency of bioconversion (considering $0.91 \mathrm{~g} / \mathrm{g}$ the theoretical value).

\section{CONCLUSIONS}

The results of this study demonstrated that rice straw hemicellulose hydrolysate treated with activated charcoal was a cheap source of xylose and other nutrients for xylitol production by Candida guilliermondii. The non-necessity of adding nutrients to the hydrolysate media could be very advantageous since the process becomes less costly. This opens up new possibilities for using this substrate in other microbial process for ethanol and enzymes production, lowering the production costs.

\section{ACKNOWLEDGEMENTS}

We gratefully acknowledge the financial support from Fundação de Amparo à Pesquisa do Estado de São Paulo (Fapesp) and Conselho Nacional de Pesquisa e Desenvolvimento (CNPq), Brazil.

\section{RESUMO}

Este trabalho avaliou a produção de xilitol pela levedura Candida guilliermondii, a partir de hidrolisado hemicelulósico de palha de arroz não tratado e tratado com carvão ativo, ambos suplementados ou não com nutrientes (sulfato de amônio, cloreto de cálcio e extrato de farelo de arroz). Os resultados mostraram que tanto o rendimento como a produtividade volumétrica em xilitol diminuíram quando os nutrientes foram adicionados em ambos hidrolisados, tratado e não tratado. Em hidrolisado tratado, a eficiência de conversão de xilose em xilitol foi de $79 \%$ quando em ausência de nutrientes. Estes resultados mostram que o hidrolisado hemicelulósico de palha de arroz tratado com carvão ativo é uma fonte barata de xilose e outros nutrientes, para a produção de xilitol por Candida guilliermondii. A não necessidade de adicionar nutrientes ao meio a base de hidrolisado é muito vantajosa, uma vez que o processo se torna mais econômico.

\section{REFERENCES}

Almeida e Silva, J. B.; Canilha, L.; Canettieri, E. V.; Felipe, M. G. A. and Solenzal, A. I. N. (2003), Use of response surface methodology to evaluate the optimum environmental conditions for the bioconversion of xylose into xylitol in eucalyptus hemicellulosic hydrolysate. J. Chem. Technol. Biot., 78, 945-948.

Azuma, M.; Ikeuchi, T.; Kiritani, R.; Kato, J. and Ooshima, H. (2000), Increase in xylitol production by Candida tropicalis upon addition of salt. Biomass Bioenerg., 19, 129-135.

Canettieri, E. V.; Almeida e Silva, J. B. and Felipe, M. G. A. (2001), Application of factorial design to the study of xylitol production from eucalyptus hemicellulosic hydrolysate. Appl. Biochem. Biotech., 94, 159-168.

Greashan, R. and Inamine, E. (1996), Nutritional improvement of processes. In: Demain, A. L. and Solomon, N. A. (Eds.). Manual of Industrial Microbiology and Biotechnology. Washington : American Society of Microbiology. pp. 41-47.

Kadam, K. L.; Forrest, L. H. and Jacobson, W. A. (2000), Rice straw as a lignocellulosic resource: collection, processing, transportation, and environmental aspects. Biomass Bioenerg., 18, 369-389.

Kuhad, R. C. and Singh, A. (1993), Lignocellulose Biotechnology: Current and Future Prospects. Crit. Ver. Biotechnol., 13, 151-172.

Mussatto, S. I. and Roberto, I. C. (2001), Hydrolysate detoxification with activated charcoal for xylitol production by Candida guilliermondii. Biotechnol. Lett., 23, 1681-1684. 
Mussatto, S. I. (2002), Influência do tratamento do hidrolisado hemicelulósico de palha de arroz na produção de xilitol por Candida guilliermondii. Master Dissertation, Faculty of Chemical Engineering of Lorena, Lorena, Brazil.

Mussatto, S. I. and Roberto, I. C. (2002), Xylitol: a sweetner with benefits for human health. Braz. J. Pharm. Sci., 38, 401-413.

Mussatto, S. I. and Roberto, I. C. (2003). Xylitol production from high xylose concentration: evaluation of the fermentation in bioreactor under different stirring rates. J. Appl. Microbiol., 95, 331-337.

Pessoa Jr., A.; Mancilha, I. M. and Sato, S. (1996), Cultivation of Candida tropicalis in sugarcane hemicellulosic hydrolysate for microbial protein production. J. Biotechnol., 51, 83-88.

Preziosi-Belloy, L.; Nolleau, V. and Navarro, J. M. (2000), Xylitol production from aspenwood hemicellulose hydrolysate by Candida guilliermondii. Biotechnol. Lett., 22, 239-243.

Roberto, I. C.; Mussatto, S. I. and Rodrigues, R. C. L. B. (2003), Dilute-acid hydrolysis for optimization of xylose recovery from rice straw in a semi-pilot reactor. Ind. Crop. Prod., 17, 171-176.

Silva, C. J. S. M. and Roberto, I. C. (1999), Statistical screening method for selection of importante variables on xylitol byosynthesis from rice straw hydrolysate by Candida guilliermondii FTI 20037. Biotechnol. Tech.,13, 743-747.

Silva, C. J. M. S. And Roberto, I. C. (2001), Improvement of xylitol production by Candida guilliermondii FTI 20037 previously adapted to rice straw hemicellulosic hydrolysate. Lett. Appl. Microbiol., 32, 248-252.

Walther, T.; Hensirisak, P. And Agblevor, F. A. (2001), The influence of aeration and hemicellulosic sugars on xylitol production by Candida tropicalis. Bioresource Technol., 76, 213-220.

Winkelhausen, E., Kuzmanova, S. (1998), Microbial conversion of d-xylose to xylitol. J. Ferment. Bioeng., 86, 1-14.

Received: February 06, 2004;

Revised: July 26, 2004;

Accepted: March 04, 2005. 